\title{
METODE PERANCANGAN STRUKTUR FUNGSI DAN PERAN TATA KELOLA DATA BERBASIS COBIT
}

\author{
Budi Yuwono dan Aditya Arinanda
}

Fakultas Ilmu Komputer, Universitas Indonesia, Kampus Baru UI Depok, Jawa Barat, 16424, Indonesia

E-mail: yuwono@cs.ui.ac.id

\begin{abstract}
Abstrak
Tulisan ini mengusulkan suatu metode untuk merancang struktur fungsi dan peran tata kelola data suatu organisasi. Metode ini berorientasi pada permasalahan, yaitu menyusun rancangan struktur berangkat dari permasalahan yang dihadapi organisasi dan memperhatikan unit-unit kerja organisasi yang ada saat ini. Tulisan ini menguraikan penerapan metode ini dalam merancang kerangka kerja tata kelola data untuk meningkatkan dan menjaga kualitas data suatu organisasi. Dari permasalahan kualitas data yang dihadapi, diidentifikasi artifak tata kelola - seperti ketentuan, standar, arsitektur yang dibutuhkan untuk mengendalikan permasalahan-permasalahan tersebut; diidentifikasi aktivitasaktivitas yang dibutuhkan untuk menghasilkan dan mengelola artifak tersebut; diidentifikasi peran dan fungsi yang terlibat dalam aktivitas-aktivitas tersebut; dan akhirnya menata peran-peran tersebut dalam suatu struktur organisasi. Tulisan ini menunjukkan bahwa struktur yang dihasilkan setara dengan struktur yang disusun berdasarkan kerangka-kerangka kerja teoritis, dengan kelebihan adanya spesifikasi tentang siapa yang layak memegang peran dalam struktur tersebut dan apa tanggung jawabnya.
\end{abstract}

Kata Kunci: tata kelola data, rancangan struktur

\begin{abstract}
This paper proposes a method for designing the function structure and of the role of an organization's data governance. The method is oriented to the problem, by arranging the structure of a draft set of issues faced by the organization and showing to organizational work units that exist today. This paper describes the application of this method in designing a data governance framework to improve and maintain the quality of organization's data. From data quality problems, we identified governance artifacts - such as regulations, standards, architecture - that is needed to control these problems; identified the activities required to generate and manage these artifacts; identified the roles and functions involved in activities these, and finally organize these roles in an organizational structure. This paper shows that the resulting structure is equivalent to a structure based on theoretical frameworks, with an excess of the specification of who should play a role in the structure and what are the responsibilities.
\end{abstract}

Keywords: data governance, structures design

\section{Pendahuluan}

Menurut Data Governance Institute, tata kelola data (data governance) adalah suatu sistem yang mengatur hak-hak dan akuntabilitas pengambilan keputusan dalam proses-proses terkait informasi, yang dilaksanakan sesuai dengan model-model yang telah disepakati untuk mengatur siapa yang boleh melakukan, terhadap informasi apa, dalam kondisi seperti apa, dan dengan metode apa [1]. Dalam implementasinya, menurut Russom [2], tata kelola data umumnya termanifestasi dalam bentuk dewan tata kelola data di tingkat eksekutif, atau forum serupa yang merumuskan dan menegakkan kebijakan serta prosedur tentang pemanfaatan dan pengelolaan teknis data yang berlaku untuk seluruh organisasi. Russom juga menyatakan bahwa tujuan umum tata kelola data adalah meningkatkan kualitas data, mengakurkan inkonsistensi data, berbagi data secara luas, memanfaatkan agregasi data untuk memperoleh keunggulan kompetitif, mengelola perubahan data dengan memperhatikan pola penggunaan data, dan mematuhi regulasi internal maupun eksternal serta standar penggunaan data yang disepakati. Pada dasarnya, tata kelola data adalah lembaga organisasi yang mengawasi penggunaan dan kegunaan data sebagai aset organisasi [2]. Beragam kerangka kerja tata kelola data dapat ditemui di banyak publikasi, namun saat ini belum ada standar atau 
praktek teruji (best practice) yang diterima secara umum untuk tata kelola data.

Tata kelola data sering diandalkan sebagai solusi atas permasalahan kualitas data organisasi. Menurut Olson [3], data yang berkualitas adalah data yang akurat,tepat waktu, relevan, lengkap, spesifik dan dapat dipercaya. Lee [4] menyatakan bahwa ada 10 faktor utama yang dapat menurunkan kualitas data, yaitu, sumber data yang beragam, subjektivitas dalam produksi data, keterbatasan sumber daya komputasi, kebutuhan akses yang mengorbankan keamanan, variasi kodifikasi data antar bidang, representasi data yang kompleks, volume data yang besar, aturan pemasukan data terlalu ketat atau tidak ada, kebutuhan data yang berubah-ubah, dan penerapan sistem-sistem yang terdistribusi dan heterogen. Adanya faktor-faktor tersebut membawa risiko kualitas data bagi organisasi.

Satu aspek yang penting dalam implementasi tata kelola data adalah rancangan struktur yang mengatur peran dan fungsi yang bertanggung jawab atas pelaksanaan proses-proses tata kelola data. Sebagaimana tata kelola teknologi informasi (information technology governance), struktur organisasi adalah salah satu komponen penting di samping proses dan kepemimpinan - dalam tata kelola data [5]. Tanpa peran dan tanggung jawab yang jelas, akan sulit untuk memastikan bahwa proses-proses tata kelola dilaksanakan secara rutin dan benar. Beberapa kerangka kerja tata kelola data seperti kerangka kerja dari Data Governance Institute hanya mempersyaratkan adanya dewan tata kelola data (data governance council) dengan keanggotaan yang merepresentasikan para pemangku kepentingan yang relevan [1].

Dalam penelitian ini, peneliti mengembangkan suatu metode untuk merancang struktur tata kelola data yang merumuskan peran dan fungsi yang terlibat dalam mengatur bagaimana organisasi mengelola datanya. Metode ini mengandalkan pada suatu kerangka kerja best practice untuk tata kelola teknologi informasi (TI), yaitu Control Objectives for Information and Related Technology (COBIT) versi 4.1 dari Information Technology Governance Institute [6]. COBIT mendefinisikan sasaran-sasaran pengendalian (control objectives) bagi organisasi untuk memastikan keselarasan antara strategi TI dan strategi organisasi sehingga manfaat bisnis dari pemanfaatan TI dapat tercipta serta risikorisiko pemanfaatan TI dapat terkendali. Dalam COBIT, sasaran-sasaran pengendalian diimplementasikan dengan proses-proses pengelolaan (mekanisme prosedural) yang di dalamnya terdapat aktivitas-aktivitas yang melibatkan fungsi-fungsi (baik bidang TI maupun non-TI) dalam organisasi.
Tulisan ini melaporkan penerapan metode yang diusulkan pada studi kasus di Direktorat Jenderal Pajak (DJP), Kementerian Keuangan Republik Indonesia. DJP termasuk lembaga pemerintah tingkat eselon 1 yang besar dengan pegawai mendekati 40 ribu orang, 330 kantorkantor pelayanan, dan wilayah yang tersebar di berbagai penjuru Indonesia. DJP mengelola data dari 18 juta lebih wajib pajak, baik perorangan maupun perusahaan, beserta data pembayaran pajaknya. Dengan volume data yang sangat besar itu, ditambah dengan banyak dan beragamnya sistem yang menjadi sumber data, kualitas data adalah permasalahan besar yang dihadapi oleh DJP.

\section{Metodologi}

Peneliti mengusulkan suatu metode untuk merancang struktur yang mendefinisikan fungsi dan peran tata kelola data yang memenuhi kebutuhan spesifik pengelolaan data suatu organisasi yang disesuaikan dengan unit-unit kerja organisasi yang ada. Metode ini dikembangkan berdasarkan asumsi tentang persyaratan wajib, tetapi bukan satu-satunya, bagi suatu tata kelola yang efektif. Asumsinya adalah bahwa tata kelola yang efektif bergantung pada terciptanya artifak tata kelola yang dirumuskan melalui proses yang melibatkan para pemangku kepentingan. Metode yang diusulkan berorientasi pada permasalahan, di mana permasalahan yang dihadapi organisasi menentukan kerangka kerja yang mendasari struktur peran dan fungsi yang akan dihasilkan. Pertama, diidentifikasi permasalahan terkait data yang dihadapi oleh organisasi. Selanjutnya, berdasarkan COBIT [6], diidentifikasi artifak tata kelola seperti kebijakan, ketentuan, atau arsitektur acuan, yang umum digunakan untuk mengatasi permasalahan yang dihadapi tersebut. Selanjutnya, diidentifikasi proses-proses yang disarankan dalam COBIT untuk menghasilkan dan memelihara artifak-artifak yang dibutuhkan. Struktur peran dan fungsi tata kelola kemudian dirancang berdasarkan fungsi-fungsi organisasi yang terlibat dalam proses-proses tersebut serta jenis keterlibatannya. Akhirnya, fungsi-fungsi dalam struktur tersebut dipetakan ke unit-unit kerja organisasi yang sudah ada. Gambar 1 menggambarkan alur dari metode perancangan struktur peran dan fungsi tata kelola data.

Satu bagian yang penting dari metode ini adalah pemetaan fungsi yang terlibat dalam proses tata kelola data beserta tanggung jawabnya, sesuai panduan COBIT, ke peran dan fungsi dalam struktur tata kelola yang dihasilkan. COBIT merumuskan 34 proses manajemen TI yang terbagi dalam empat domain proses, yaitu 
Perencanaan dan Pengorganisasian (PO, Plan \& Organize), Akuisisi dan Implementasi (AI, Acquire \& Implement), Penyediaan Layanan dan Dukungan (DS, Deliver \& Support), serta Pengukuran dan Evaluasi (ME, Measure \& Evaluate). Untuk setiap proses, COBIT memberikan syarat seperangkat tujuan-tujuan pengendalian (control objective) serta aktivitasaktivitas kunci yang harus ada dalam proses untuk memenuhi sasaran-sasaran pengendalian tersebut. Untuk setiap aktivitas kunci, COBIT memberikan fungsi-fungsi (unit-unit kerja) dalam organisasi yang semestinya terlibat dalam aktivitas tersebut, dalam format tabel RACI (Responsible Accountable - Consulted - Informed) [6]. Setiap fungsi organisasi yang terlibat dalam aktivitas tersebut memiliki jenis keterlibatan tertentu. Jenis-jenis keterlibatan yang mungkin adalah: Responsible - menjadi pihak pelaksana aktivitas tersebut. Accountable - menjadi pihak penanggung-jawab atas terselesainya aktivitas dan hasilnya, pelaksanaanya sendiri dapat didelegasikan ke pihak lain. Untuk setiap aktivitas hanya boleh ada satu pihak yang accountable. Consulted - menjadi pihak yang dimintai pendapat sebagai masukan bagi aktivitas tersebut. Informed - menjadi pihak yang diberitahukan mengenai hasil aktivitas tersebut.

Berdasarkan definisi jenis keterlibatan di atas, peneliti mengembangkan seperangkat aturan untuk memetakan fungsi organisasi dan jenis keterlibatannya menurut COBIT menjadi suatu struktur organisasi. Pertama, pihak responsible yang ditugaskan melaksanakan aktivitas diposisikan di bawah pihak accountable yang memberi tugas. Jika pihak yang accountable juga sebagai pihak yang responsible maka pihak tersebut diposisikan di bawah pihak yang informed.

Kedua, pihak-pihak yang consulted dikelompokkan berdasarkan bidang yang menjadi kewenangannya. Dalam konteks tata kelola data, ada dua kelompok bidang utama, yaitu bidang bisnis dan bidang teknologi informasi. Masingmasing kelompok bidang menghasilkan artifak yang menjadi masukan bagi aktivitas tata kelola. Ketiga, perwakilan dari pihak-pihak yang informed dikelompokkan menjadi suatu komite atau dewan, yang juga beranggotakan pihak yang accountable, dengan tanggung jawab mengomunikasikan dan memastikan diberlakukannya hasil aktivitas tata kelola oleh seluruh organisasi.

Keempat, setiap komite diberi nama sesuai dengan artifak tata kelola yang diawasinya, misalnya komite arsitektur, dan sebagainya. Kelima, unit kepatuhan, audit, risiko, dan pengamanan dituntut untuk menjaga independensi dan melaporkan langsung kepada eksekutif puncak, sehingga tidak dikelompokkan dengan pihak lain ke dalam suatu komite.

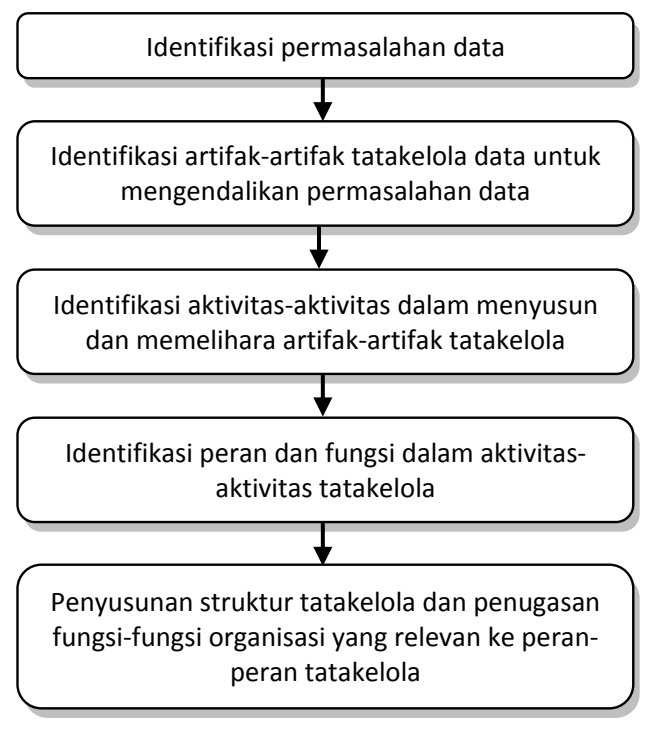

Gambar 1. Alur metode perancangan struktur peran dan fungsi tata kelola data.

Untuk mengevaluasi validitas dari struktur peran dan fungsi yang dihasilkan dengan metode ini, peneliti bandingkan struktur tersebut dengan struktur teoritis yang disusun terutama berdasarkan penelitian Dyche \& Levy [7][8], dengan membandingkan kesamaan atau perbedaan di antara keduanya. Kerangka kerja teoritis menyatakan bahwa struktur organisasi tata kelola data terdiri dari peran-peran sebagai berikut, yaitu Data Governance Council (Dewan Tata kelola Data), Corporate Data Steward (Pemandu Data Organisasi), Business Data Steward (Pemandu Data Bisnis), dan Source Systems Data Steward (Pemandu Data Sistem Pengolahan Data). Hubungan struktural peranperan tersebut digambarkan sebagaimana pada gambar 2 .

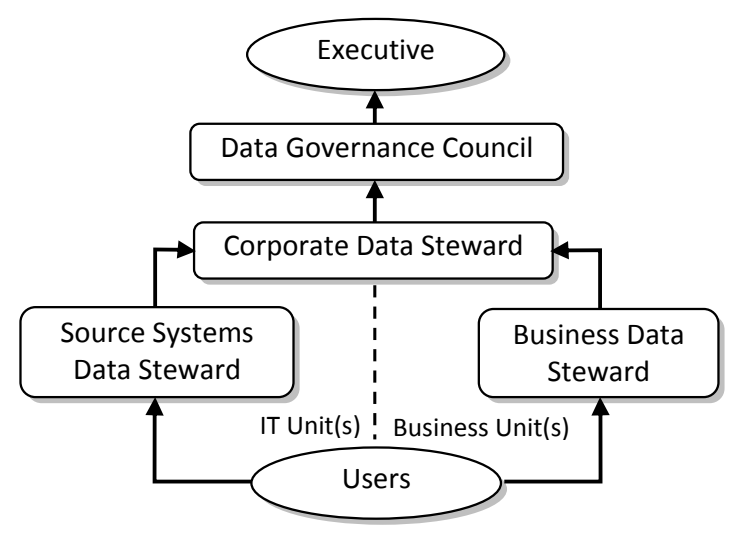

Gambar 2. Hubungan struktural tata kelola data teoritis. 
Tabel I mendeskripsikan tanggung jawab dari setiap peran dalam struktur tata kelola data teoritis.

TABEL I

TANGgung JaWAB Fungsional SETIAP PERAN DALAM STRUKTUR TATA KELOLA DATA TEORITIS

\begin{tabular}{ll}
\hline \hline Peran & Tanggung jawab \\
\hline Data Governance & $\begin{array}{l}\text { Merumuskan dan menetapkan } \\
\text { kebijakan (ketentuan dan prosedur) } \\
\text { serta standar data organisasi }\end{array}$ \\
Corporate Data & $\begin{array}{l}\text { Mengelola standar dan penerapan } \\
\text { kebijakan (ketentuan dan prosedur) } \\
\text { Steward/Management } \\
\text { data organisasi }\end{array}$ \\
Business Data & $\begin{array}{l}\text { Merumuskan standar dan kebijakan } \\
\text { Steward }\end{array}$ \\
teknis untuk bidang bisnis masing- \\
masing
\end{tabular}

\section{Analisis dan Pembahasan}

Dari wawancara dengan dua pimpinan unit yang mengelola proses-proses bisnis utama organisasi, diperoleh daftar permasalahan yang mencerminkan rendahnya kualitas data [7]. Tabel II adalah daftar permasalahan beserta artifak tata kelola berbasis COBIT yang umumnya digunakan untuk mengatasi permasalahan-permasalahan tersebut. Notasi dalam tanda kurung menyatakan kode sasaran pengendalian COBIT yang memanfaatkan artifak tersebut.

Dengan mengacu pada panduan COBIT untuk proses Define the Information Architecture (PO2) diperoleh deskripsi dari aktivitas-aktivitas yang terkait dengan penyusunan dan pengelolaan artifak-artifak tata kelola yang disebutkan pada tabel II. Tabel III adalah daftar aktivitas-aktivitas tersebut dan fungsi-fungsi organisasi yang berperan dalam tiap aktivitas. Tipe keterlibatannya adalah A untuk accountable, $\mathrm{R}$ untuk responsible, $\mathrm{C}$ untuk consulted, dan I untuk informed. Berdasarkan tipe keterlibatan dari fungsi-fungsi umum dalam aktivitas-aktivitas kunci tersebut, dibentuk suatu struktur hubungan dengan metode yang telah dibahas sebelumnya, sehingga dihasilkan struktur sebagaimana terlihat di gambar 3.

Dengan mengacu pada deskripsi sasaransasaran pengendalian COBIT PO2.1, PO2.2, PO2.4, dirumuskan tanggung jawab fungsional untuk setiap peran tata kelola data pada tabel III. Tabel IV menguraikan tanggung jawab dari peranperan tata kelola data tersebut.

Terlihat bahwa terdapat kesamaan antara peran dan fungsi tata kelola data yang dihasilkan dengan yang ada pada kerangka kerja teoritis sebagaimana diuraikan pada tabel I. Struktur yang dihasilkan memberikan rincian dalam hal keanggotaan tiap peran dan tanggung jawab fungsionalnya. Kelebihan ini dapat memudahkan penerapannya pada organisasi nyata. Tabel V menguraikan keanggotaan peran-peran tata kelola data dalam penerapannya di Direktorat Jenderal Pajak, berdasarkan pemetaan antara fungsi-fungsi umum organisasi menurut COBIT dan unit-unit kerja yang sepadan (memiliki tanggung-jawab yang serupa berdasarkan deskripsi tugas resminya) dalam organisasi [9].

TABEL II

PERMASAlahan Kualitas Data YANG Dilaporkan DaN ARTIFAK TATA KELOLA BERBASIS COBIT UNTUK MENGATASINYA

\begin{tabular}{|c|c|c|}
\hline $\mathrm{Nc}$ & Problem & 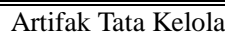 \\
\hline 1 & $\begin{array}{l}\text { Tidak tersedianya data pembanding } \\
\text { eksternal dengan struktur yang } \\
\text { sesuai untuk memvalidasi data } \\
\text { wajib pajak }\end{array}$ & $\begin{array}{l}\text { Enterprise } \\
\text { Information } \\
\text { Architecture } \\
\text { (PO2.1) }\end{array}$ \\
\hline 2 & $\begin{array}{l}\text { Kurangnya koordinasi untuk } \\
\text { menjaga konsistensi struktur data } \\
\text { antar aplikasi-aplikasi organisasi }\end{array}$ & $\begin{array}{l}\text { Enterprise Data } \\
\text { Dictionary (PO2.2) }\end{array}$ \\
\hline 3 & $\begin{array}{l}\text { Tidak adanya metadata yang } \\
\text { mencakup data seluruh organisasi }\end{array}$ & $\begin{array}{l}\text { Enterprise Data } \\
\text { Dictionary (PO2.2) }\end{array}$ \\
\hline 4 & $\begin{array}{l}\text { Tidak adanya mekanisme } \\
\text { terotomasi untuk menjaga validitas } \\
\text { data } \text { input }\end{array}$ & $\begin{array}{l}\text { Optimized } \\
\text { Business System } \\
\text { Plan (PO2.4) }\end{array}$ \\
\hline 5 & $\begin{array}{l}\text { Kurangnya partisipasi unit pemilik } \\
\text { data dalam perancangan sistem } \\
\text { pengolahan data }\end{array}$ & $\begin{array}{l}\text { Optimized } \\
\text { Business System } \\
\text { Plan }(\mathrm{PO} 2.4)\end{array}$ \\
\hline 6 & $\begin{array}{l}\text { Kurangnya pengetahuan tentang } \\
\text { proses bisnis (domain) di pihak } \\
\text { analis sistem TI. }\end{array}$ & $\begin{array}{l}\text { Optimized } \\
\text { Business System } \\
\text { Plan (PO2.4) }\end{array}$ \\
\hline
\end{tabular}

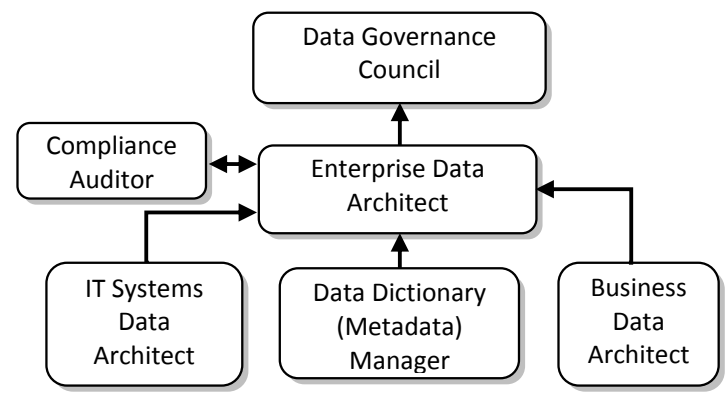

Gambar 3. Struktur hubungan antara peran-peran yang terlibat dalam tata kelola data organisasi.

\section{Kesimpulan}

Tulisan ini telah menguraikan suatu metode usulan untuk mengembangkan struktur peran dan fungsi tata kelola data organisasi. Telah ditunjukkan pula bahwa metode ini dapat menghasilkan kerangka kerja rinci yang lebih mudah diimplementasikan dalam organisasi nyata dibandingkan beberapa kerangka kerja teoritis.

Peneliti yakin bahwa pendekatan serupa juga dapat digunakan untuk mengembangkan struktur tata kelola selain tata kelola data. Akan tetapi, metode ini dirasa kurang sesuai untuk menyusun struktur peran dan fungsi untuk proses-proses selain pengelolaan artifak tata kelola (kebijakan 
dan standar) yang terfokus pada interaksi antar pihak-pihak terkait untuk berkoordinasi dalam rangka menciptakan keselarasan.

TABEL III

AKTIVITAS-AKTIVITAS YANG MEMPRODUKSI DAN MENJAGA ARTIFAK-ARTIFAK TATA KELOLA YANG DIBUTUHKAN DAN FUNGSI-FUNGSI UMUM ORGANISASI YANG TERLIBAT

\begin{tabular}{|c|c|c|}
\hline \multicolumn{3}{|c|}{ BERDASARKAN COBIT } \\
\hline Artifak & Aktivitas & Fungsi \& Peran \\
\hline $\begin{array}{l}\text { Enterprise } \\
\text { Information } \\
\text { Architecture }\end{array}$ & $\begin{array}{l}\text { Menyusun } \\
\text { dan merevisi } \\
\text { model } \\
\text { informasi } \\
\text { organisasi }\end{array}$ & $\begin{array}{l}\text { CIO (A), Chief Architect }(\mathrm{R}), \\
\text { Business Process Owner }(\mathrm{C}), \\
\text { Head of Development }(\mathrm{C}), \\
\text { Head of IT Administration } \\
\text { (C), Compliance-Audit-Risks- } \\
\text { Security }(\mathrm{C}), \text { CFO }(\mathrm{C}), \\
\text { Business Executive }(\mathrm{I})\end{array}$ \\
\hline $\begin{array}{l}\text { Enterprise } \\
\text { Data } \\
\text { Dictionary }\end{array}$ & $\begin{array}{l}\text { Menyusun } \\
\text { dan merevisi } \\
\text { kamus data } \\
\text { organisasi }\end{array}$ & $\begin{array}{l}\text { Chief Architect }(\mathrm{A} / \mathrm{R}), \text { Head } \\
\text { of Development }(\mathrm{R}), \text { Business } \\
\text { Process Owner }(\mathrm{C}), \\
\text { Compliance-Audit-Risks- } \\
\text { Security }(\mathrm{C}), \text { CIO }(\mathrm{I})\end{array}$ \\
\hline $\begin{array}{l}\text { Optimized } \\
\text { Business } \\
\text { Systems } \\
\text { Plan }\end{array}$ & $\begin{array}{l}\text { Menggunakan } \\
\text { model } \\
\text { informasi, } \\
\text { kamus data, } \\
\text { dan ketentuan } \\
\text { klasifikasi } \\
\text { data untuk } \\
\text { merancang } \\
\text { sistem yang } \\
\text { optimal }\end{array}$ & $\begin{array}{l}\text { CIO }(\mathrm{A}), \text { Chief Architect }(\mathrm{R}), \\
\text { Business Process Owner }(\mathrm{C}), \\
\text { CEO }(\mathrm{C}), \text { CFO }(\mathrm{C}), \\
\text { Compliance-Audit-Risks- } \\
\text { Security (I), Business } \\
\text { Executive (I) }\end{array}$ \\
\hline
\end{tabular}

TABEL IV

Peran-Peran Tata Kelola Data Organisasi, KEANGGOTAANNYA DAN TANGGUNG JAWAB FUnGSIONALNYA

\begin{tabular}{|c|c|c|}
\hline Peran & Anggota & Tanggung Jawab \\
\hline Data & Business & Merumuskan kebijakan \\
\hline Governance & Executives, & untuk memastikan integritas \\
\hline Council & $\mathrm{CIO}$ & $\begin{array}{l}\text { dan konsistensi semua data } \\
\text { yang disimpan dalam } \\
\text { format elektronik, seperti } \\
\text { database, data warehouse } \\
\text { dan arsip data elektronik }\end{array}$ \\
\hline $\begin{array}{l}\text { Enterprise } \\
\text { Data } \\
\text { Architect }\end{array}$ & Chief Architect & $\begin{array}{l}\text { Menetapkan dan mengelola } \\
\text { model informasi organisasi } \\
\text { untuk mendukung } \\
\text { pengembangan aplikasi dan } \\
\text { pengambilan keputusan TI } \\
\text { agar konsisten dengan } \\
\text { rencana TI organisasi }\end{array}$ \\
\hline Data & Head of & Mengelola kamus data \\
\hline Dictionary & (Application) & organisasi yang mencakup \\
\hline $\begin{array}{l}\text { (Metadata) } \\
\text { Manager }\end{array}$ & Development & $\begin{array}{l}\text { aturan kodifikasi data } \\
\text { organisasi }\end{array}$ \\
\hline IT Systems & Head of & Menetapkan dan mengelola \\
\hline Data & (Database) & model-model data pada \\
\hline Architect & Administration & sistem-sistem TI \\
\hline Business & CFO, Business & Menetapkan dan mengelola \\
\hline Data & Process & model-model data bisnis/ \\
\hline Architects & Owners & administratif \\
\hline Compliance & Compliance, & Mengaudit kepatuhan \\
\hline Auditor & Audit, Risks & satuan-satuan kerja pada \\
\hline & and Security & $\begin{array}{l}\text { kebijakan dan standar data } \\
\text { yang ditetapkan }\end{array}$ \\
\hline
\end{tabular}

TABEL V

Peran Tatakelola Data dan Pejabat serta Satuan Kerja DiREKTORAT JENDERAL PAJAK YANG TERLIBAT DALAM SETIAP PERAN

\begin{tabular}{|c|c|}
\hline Name & Members \\
\hline Dewan Tata & Direktur Transformasi Teknologi Informasi \\
\hline \multirow[t]{3}{*}{ kelola Data } & Komunikasi dan Informasi, Direktur \\
\hline & Teknologi Informasi Perpajakan, Direktur \\
\hline & Transformasi Proses Bisnis \\
\hline Arsitek Data & Subdirektorat Analisis dan Evaluasi Sistem \\
\hline \multirow[t]{2}{*}{ Organisasi } & Informasi (Seksi Perancangan Sistem dan \\
\hline & Prosedur Perpajakan) \\
\hline Manajer & Subdirektorat Pengembangan Aplikasi \\
\hline Metadata & $\begin{array}{l}\text { (Seksi Pengembangan Aplikasi Informasi } \\
\text { dan Pelaporan) }\end{array}$ \\
\hline Arsitek Data & Subdirektorat Pengembangan Perangkat \\
\hline Sistem & Keras (Seksi Pengelolaan Basis Data) \\
\hline Arsitek Data & Subdirektorat Pengembangan Pelayanan \\
\hline Bisnis & (semua seksi) \\
\hline Auditor & Subdirektorat Kepatuhan Internal (Seksi \\
\hline Kepatuhan & Pengujian Kepatuhan) \\
\hline
\end{tabular}

\section{Referensi}

[1] Data Governance Institute, The DGI Data Governance Framework, 2005.

[2] P. Russom, The Four Imperatives of Data Governance Maturity, TDWI Monograph Series, The Data Warehouse Institute, 2008

[3] J. Olson, Data Quality: The Accuracy Dimension, Morgan Kauffman Publishers, San Fransisco, 2003.

[4] Y.W. Lee, L.L. Pipino, J.D. Funk, \& R.Y. Wang, Journey to Data Quality, The MIT Press, Boston, 2006.

[5] IT Governance Institute, Board Briefing on IT Governance, 2nd ed., ITGI, USA, 2003.

[6] IT Governance Institute, "COBIT 4.1: Control Objectives, Management Guidelines”, Maturity Models, USA, 2007.

[7] A. Arinanda, "Perancangan Struktur Data Governance Untuk Membentuk Strategi Manajemen Kualitas Data: Studi Kasus Direktorat Jenderal Pajak," Ph.D Thesis, Magister of Information Technology, Universitas Indonesia, Indonesia, 2010.

[8] J. Dyche \& E. Levy, Customer Data Integration: Reaching a Single Version of the Truth, John Wiley \& Sons, Inc. Hoboken, New Jersey, 2006.

[9] Menteri Keuangan, "Peraturan Menteri Keuangan 100/PMK.01/2008 - Organisasi dan Tata Kerja Departemen Keuangan”, Kementerian Keuangan Republik Indonesia, 2008. 